\title{
A Classification of Luxury Fashion Brands' E-commerce Sites
}

\author{
Kim Sunghee \\ Dept. of Fashion Design, Woosuk University
}

\begin{abstract}
The aim of this study was to analyze e-commerce sites of luxury fashion brands in order to provide insights on how to enhance online site quality. For the research, forty-eight components of thirty-one luxury fashion brands' e-commerce sites were investigated during October 2013. For the analysis of clustering e-commerce site components and segmenting e-commerce sites of luxury brands, a hierarchical cluster analysis was applied through using the Ward's method and squared Euclidian distance for binary data. Further, Fisher's exact test was applied in order to distinguish three groups of characteristics in the luxury e-commerce sites. These analyses were carried out by SPSS 21.

The result indicated that the components of e-commerce sites were grouped into three categories: basic elements, additional elements and elements of building brand identity. These components were categorized by whether their functions were basic and essential or additional and advanced. The other norm of categorization was related to brand identity.

Furthermore, the luxury brands' e-commerce sites were segmented into three groups: a group of endeavoring to promote goods, a group of undistinguished performance, and a group of endeavoring to intensify brand identity. In this segmentation, brand identity or promotional aspects were decisive.

Overall, luxury brands were trying to convey their traditional strength through their e-commerce sites. In order to achieve this purpose, brand identity or promotional aspects played an important role.
\end{abstract}

Key words : luxury brand e-commerce site components, luxury fashion brand segmentation

\section{Introduction}

Luxury market grew on a worldwide scale over the last two decades but the sudden global recession in 2008 cooled down the luxury market. Since then the market has headed for the slowest year of growth. In order to reverse the subsiding market trend, luxury brands began to take a big step into e-commerce but many

Corresponding author: Kim Sunghee, Tel. +82-63-290-1541, Fax. +82-63-290-1541

E-mail: regina541@naver.com 
luxury brands were still skeptical of recreating the luxury bricks-and-mortar experience into a digital world.

In fact, luxury products were difficult to sell online. Only few luxury goods have been sold on e-commerce site as reduced prices. But in recent days, the significantly increasing use of the internet as a shopping medium has broken away from the traditional thinking of their customers. Many luxury brands are now focusing on developing an online presence. Thus the examination of official web sites of luxury fashion brands becomes necessary.

Although the accumulated studies on luxury brands exist, there are not sufficient studies about e-commerce. Research on luxury brand has been conducted in diverse perspectives. First, related to luxury consumers' behavior, researchers studied conspicuous consumption (O'Cass \& McEwen, 2004; Rhee, 2008; Truong, Simmons, McColl, \& Kitchen, 2008); consumer desire for luxury goods (J. Lee \& Kim, 2007); purchasing behavior of luxury goods (Han, 2007; Hierang Park \& Hahn, 2006); consumers' luxury brand identification (S. Kim \& Chung, 2006; J. Shin, Kong, \& Kang, 2006); consumers' luxury brand attachment (K. Ahn, Lee, \& Jeon, 2008; S. Kim, \& Kim, 2009) and consumer's attitudes toward luxury brands (Jina Park, 2010; Juyoung Park, Lee, \& Choi, 2008). Second, respect to marketing side, there were studies of the channel selection of luxury goods (Hyesun Park \& Kim, 2011; S. Shin \& Kim, 2006) luxury brand differentiation (Haeshin Park, 2010; Jung, 2010) luxury market segments (Dubois, Czellar, \& Laurent, 2005; Yoon \& Han, 2008); Iuxury fashion brand equity (Y. Choi \& Rhee, 2004; Jungwon Park, 2008) and luxury brand extensions (Dubois \& Czellar, 2002; Hennings, Wiedmann, Behrens, Klarmann, \& Carduck, 2013;
Reddy, Terblanche, Pitt, \& Parent, 2009). Third, in relation to counterfeit consumption, consumers' attitude toward counterfeit goods were investigated (Hyejung Park \& Jeon, 2006; S. Lee, 2006; Rha, Rhee, Yeo, Kim, \& Jun, 2010). Forth, in terms of the socio-cultural approach of luxury fashion goods, research were conducted on cultural marketing (Mun \& Huh, 2006); social, economic, and cultural aspect (M. Park, 2006) and cultural sociological perspective (S. Choi \& Jin, 2006).

Despite the extensive body of knowledge were built up relating luxury fashion goods, research on luxury fashion brand's e-commerce site is scarce. Therefore this study examined official e-commerce sites of luxury fashion brands to aim to give the basic framework of e-commerce, which included the analysis of luxury brands e-commerce sites' components and e-commerce sites' segmentation.

\section{Literature review}

\section{2-1. Defining luxury brands}

The word "luxury" is commonly used in daily life but the definition of Luxury is vague. For instance, luxury brands were variously named such as prestige brands, foreign brands, famous imported brands, imported high-end brands, etc.

With reference to luxury brands, Panigyrakkis and Koronaki (2011) classified the studies on luxury brands' definition into three categories, by the norms of De Barnier and Rodina (2000). From the economic perspectives, luxury was defined that it was distinct from necessity and rarity was essential; from psychological viewpoint, studies dealt with consumers' "interpersonal or external" factors, and "personal 
or internal" factors; in terms of marketing, studies focused on the difference between "luxury and non-luxury" and luxury's attributes.

Related to luxury definition, Dubois, Laurent, and Czellar (2001) found six features of luxury based on content analysis of in-depth interviews: "excellent quality," "very high price," "scarcity and uniqueness," "aesthetics and polysensuality," "ancestral heritage and personal history," and "superfluousness." Berverland (2004) sought to find features of luxury wine brands that were "product integrity," "history," "value driven emergence," "culture," "marketing," and "endorsements." M. Choi and Kim (2005) highlighted four features that were reputation, craftsmanship, tradition, and rarity. Moore and Britwistle (2005) discriminated elements of the luxury fashion brands from previous study of Berland's that were "premium pricing," "flagship stores \& store brand concept," "culture/heritage," "iconic products/design," "product integrity," "marketing," and "endorsements." E. Choi, Hong, and Lee (2010) proposed luxury fashion brand components on three dimensions: functional aspect such as "high quality," "high price," "unique design," and "luxury store"; emotional aspect such as "craftsmanship," "VIP service," and "high social status"; symbolic aspect such as "brand heritage" and "being a well-known brand." Tynan, McKechnie, and Chhuon (2009) uncovered key identifiers of luxury brands that were "high quality," "expensive," "rare," "exclusive," prestigious," "authentic," "high level of symbolic," and "emotional/hedonic values." Armatulli and Guido (2011) investigated attributes of fashion luxury goods such as "quality," "craftsmanship," "tailored," "very expensive," "inaccessible," "innovative," "secure," "design," "trendy," "functional," and "natural."

When indicating the attributes of luxury, high price, high quality, and culture/history were commonly included. Moreover, symbolic, rarity, and craftsmanship/technology were connected to definition of luxury (Table1). Hence, it is necessary to investigate how the diverse features of luxury definition can be applied to generate e-commerce site's atmosphere of luxury brand.

\section{2-2. Web site studies}

Much of the studies on web site mainly focused on consumers' evaluation about web sites. Aladwani and Palvia (2002) uncovered four dimensions of web quality based on 25-item instrument: "specific content" (finding contact information, firm information, products/services details, consumer's policies, and customer's support); "content quality" (usefulness, completeness, clarity, currency, conciseness, and accuracy); "appearance" (attractiveness, organization, proper fonts, proper colors, proper use of multimedia); and "technical adequacy" (security, ease of navigation, availability, valid links, etc.). T. Ahn, Ryu, and Han (2004) dealt with user acceptance of internet shopping mall's dual natures including online and offline attributes: online features including "system quality" (design, navigation, response time, system security, etc.), "information quality" (contents variety, complete information, detail information, accurate information, timely information, etc.), "service quality" (responsiveness, reliability, confidence, empathy, etc.); offline features such as "product quality" (product quality, product variety, and product availability) and "delivery service" (reliable delivery, package safety, timely delivery, and return easiness). Ranganathan and Ganapathy (2002) examined online consumers' 
Table 1. The Attributes of Luxury

\begin{tabular}{|c|c|c|c|c|c|c|c|c|}
\hline Studies & $\begin{array}{l}\text { High } \\
\text { price }\end{array}$ & $\begin{array}{l}\text { High } \\
\text { quality }\end{array}$ & Symbolic & Rarity & $\begin{array}{l}\text { Culture } \\
\text { and } \\
\text { history }\end{array}$ & $\begin{array}{l}\text { Craftsmans } \\
\text { hip and } \\
\text { technology }\end{array}$ & Marketing & Etc. \\
\hline $\begin{array}{l}\text { Dubois et al. } \\
\text { (2001) }\end{array}$ & 0 & 0 & & 0 & 0 & & & $\begin{array}{c}\text { aesthetics, } \\
\text { poly-sensuality }\end{array}$ \\
\hline $\begin{array}{l}\text { Berverland } \\
\text { (2004) }\end{array}$ & & 0 & & & 0 & & 0 & $\begin{array}{l}\text { value driven, } \\
\text { emergence, } \\
\text { endorsement }\end{array}$ \\
\hline $\begin{array}{l}\text { M. Choi \& Kim } \\
(2005)\end{array}$ & & & & 0 & 0 & 0 & & reputation \\
\hline $\begin{array}{l}\text { Moore \& } \\
\text { Birtwistle } \\
\text { (2005) }\end{array}$ & 0 & 0 & 0 & & 0 & & 0 & $\begin{array}{c}\text { flagship stores } \\
\text { \& store brand } \\
\text { concept, } \\
\text { endorsements }\end{array}$ \\
\hline $\begin{array}{l}\text { E. Choi et al. } \\
\text { (2010) }\end{array}$ & 0 & 0 & 0 & & 0 & 0 & & $\begin{array}{l}\text { unique design, } \\
\text { luxury store, } \\
\text { VIP service, } \\
\text { being a } \\
\text { well-known } \\
\text { brand }\end{array}$ \\
\hline $\begin{array}{l}\text { Tynan et al. } \\
\text { (2010) }\end{array}$ & 0 & 0 & 0 & 0 & & & & $\begin{array}{c}\text { exclusive, } \\
\text { prestigious, } \\
\text { authentic, } \\
\text { emotional/ } \\
\text { hedonic values }\end{array}$ \\
\hline $\begin{array}{l}\text { Amatulli \& } \\
\text { Guido (2011) }\end{array}$ & 0 & 0 & & & & 0 & & $\begin{array}{c}\text { tailored, } \\
\text { innovative, } \\
\text { secure, design, } \\
\text { trendy, } \\
\text { functional, } \\
\text { natural }\end{array}$ \\
\hline
\end{tabular}

purchase intention to find web sites dimension: information content, design, security, and privacy. Y. Lee and Kozar (2006) found four components in terms of web site quality attributes: "information quality" (relevance, currency, and understandability), "service quality" (empathy, reliability, and responsiveness), "systems quality" (navigability, response time, personalization, telepresence, and security), and "vendor-specific quality" (awareness, reputation, and price savings). Koo (2006) defined online store attributes such as web site design, visual appeal, hyperlinks, product assortment, information, security feature, and after-sale services. 
Little study has examined web site attributes from the different perspective. T. Kim and Kim (2010) postulated that web site features needed to be analyzed from the seller's side. They found the web site aspects affecting seller's satisfaction such as image factor, web site system factor, and information factor.

While a great amount of research has examined the consumer's evaluation on web site, there have been few attempts to analyze web site contents. Spiller and Lohse (1997) observed 137 retail web sites using 44 variables of web site contents in order to classify online retail stores. Later they focused on "super store," one of five categories of web retail site, to diagnose interface design features' affecting super store's traffic and sales (Lohse \& Spiller, 1998). Huizingh (2000) differentiated content from design in terms of web site. He defined "content" (including information, transaction, entertainment, and advanced site) and "perception of content"; "design" (navigation structure, search function and protected contents) and "perception of design" (quality of the structure, image, and presentation style). Baloglu and Pekcan (2006) identified upscale hotels' web sites attributes such as interactivity, navigation, functionality, and marketing aspects. Yang and Lee (2006) analyzed internet apparel shopping sites and found three components of the sites: user interface, merchandise information, and customer service.

As mentioned earlier, there are not enough studies on web site contents since the study of web site components are mostly related to consumers' evaluation of the sites. Based on the scarce studies on web components, it is shown that merchandise and service are common factor of the sites. And the other elements like promotion, user interface, or marketing aspects are added to those elements (Table 2).

Table 2. The Attributes of Web Site Contents

\begin{tabular}{l|l}
\hline \multicolumn{1}{c|}{ Researchers } & \multicolumn{1}{c}{ Web site attributes } \\
\hline Spiller \& Lohse (1997) & $\begin{array}{l}\text { Merchandise, service, promotion, other store variables, and user } \\
\text { interface }\end{array}$ \\
\hline Lohse \& Spiller (1998) & Merchandise, service, promotion, convenience, and user interface \\
\hline Huizingh (2000) & $\begin{array}{l}\text { Content (information, transaction, entertainment, advanced site) and } \\
\text { perception of content } \\
\text { Design (navigation structure, search function, and protected } \\
\text { contents) and perception of design (quality of the structure, image, } \\
\text { and presentation style) }\end{array}$ \\
\hline Baloglu \& Pekcan (2006) & Interactivity, navigation, functionality, and marketing \\
\hline Yang \& Lee (2006) & User interface, merchandise information, and customer service \\
\hline \hline
\end{tabular}




\section{Research Methodology}

The aim of this study was to analyze e-commerce site components of luxury fashion brands and to segment e-commerce sites based on their site components. In order to achieve this goal, thirty-one luxury fashion e-commerce sites were conveniently selected. These were listed both on Luxury brand index (Okonkwo, 2007) and on Digital IQ index: Fashion (Galloway, 2012). And they sold products online since they used a digital medium as an important marketing tool.

For a preliminary investigation, sixty-four variables were used based on the web structure of Spillerand Lohse (1998): merchandise, service, convenience, and promotion except user interface. And the components were corded in binary indicating presence (1) and absence (0) of attributes. For final analysis, the rarely appearing components were excluded and forty-eight components were used: merchandise (product name, product code, product description, price, color, material, pictures, size); service (legal area, shipping, return, privacy policy, contact us, live chat, see the packaging); convenience (shopping bag, wish list, search, login, view all, magnifying product, video showing full degree of the product, size chart, fit suggestion, cursor, just seen); and promotion (gift category, gift guide, new arrival, pick, shop sale, holiday collection, contact fashion advisor, SNS, share site, Flike, comment on SNS, link the APP, collection, looks, newsletter, campaigns, special projects, philanthropy, collaboration, craftsmanship, star marketing, heritage). And the survey was conducted during October 2013 and the analysis was carried out by SPSS 21 .
Data analysis of the survey was twofold. The first analysis classified components of e-commerce site by using hierarchical cluster analysis. Hierarchical cluster analysis was applied because it could cluster binary data and also categorize not only cases but also variables. The second analysis segmented luxury fashion brands' e-commerce sites based on their site components. And the segmented groups' attributes were analyzed by Fisher's exact test.

\section{Results}

\section{4-1. Clusters of luxury fashion brand e-commerce sites' components}

In order to recognize how components of e-commerce site were categorized, hierarchical cluster analysis was applied. Hierarchical clusters were generated using Ward's method and squared Euclidean distance for binary data set. The number of clusters of variables was determined by agglomeration schedule of table 3. It shows how far the agglomeration algorithm has to reach to combine an existing cluster with the next closest variable. For this example one can see that there is a large jump between stages 46 and 47 . "The big leap occurs at the end of stage all the time therefore agglomeration stop rule can be applied to right before the last stage," according to the study of Hair, Black, Babin, and Anderson (as cited in H. Lee \& Lim, 2013, p. 462). As a result, the luxury brands e-commerce sites' components were classified into three groups. 
Kim Sunghee / A Classification of Luxury Fashion Brands' E-commerce Sites

Table 3. Agglomeration Schedule of Luxury Fashion Brand E-commerce Sites' Components

\begin{tabular}{|c|c|c|c|c|c|c|}
\hline \multirow{2}{*}{ Stage } & \multicolumn{2}{|c|}{ Cluster Combined } & \multirow{2}{*}{ Coefficients } & \multicolumn{2}{|c|}{ Stage Cluster First Appears } & \multirow{2}{*}{ Next Stage } \\
\hline & Cluster 1 & Cluster 2 & & Cluster 1 & Cluster 2 & \\
\hline 1 & 46 & 47 & .000 & 0 & 0 & 2 \\
\hline 2 & 42 & 46 & .000 & 0 & 1 & 4 \\
\hline 3 & 44 & 45 & .000 & 0 & 0 & 4 \\
\hline 4 & 42 & 44 & .000 & 2 & 3 & 5 \\
\hline 5 & 42 & 43 & .000 & 4 & 0 & 8 \\
\hline 6 & 39 & 40 & .000 & 0 & 0 & 12 \\
\hline 7 & 5 & 10 & .000 & 0 & 0 & 15 \\
\hline 8 & 3 & 42 & .857 & 0 & 5 & 9 \\
\hline 9 & 3 & 24 & 1.750 & 8 & 0 & 15 \\
\hline 10 & 1 & 14 & 2.750 & 0 & 0 & 22 \\
\hline 11 & 12 & 13 & 3.750 & 0 & 0 & 18 \\
\hline 12 & 17 & 39 & 5.083 & 0 & 6 & 24 \\
\hline 13 & 38 & 41 & 6.583 & 0 & 0 & 26 \\
\hline 14 & 6 & 26 & 8.083 & 0 & 0 & 22 \\
\hline 15 & 3 & 5 & 9.733 & 9 & 7 & 24 \\
\hline 16 & 9 & 36 & 11.733 & 0 & 0 & 21 \\
\hline 17 & 4 & 25 & 13.733 & 0 & 0 & 35 \\
\hline 18 & 12 & 18 & 16.067 & 11 & 0 & 42 \\
\hline 19 & 20 & 48 & 18.567 & 0 & 0 & 40 \\
\hline 20 & 27 & 28 & 21.067 & 0 & 0 & 30 \\
\hline 21 & 9 & 16 & 23.733 & 16 & 0 & 23 \\
\hline 22 & 1 & 6 & 26.483 & 10 & 14 & 34 \\
\hline 23 & 7 & 9 & 29.317 & 0 & 21 & 29 \\
\hline 24 & 3 & 17 & 32.276 & 15 & 12 & 35 \\
\hline 25 & 33 & 35 & 35.276 & 0 & 0 & 43 \\
\hline 26 & 15 & 38 & 38.442 & 0 & 13 & 32 \\
\hline 27 & 22 & 23 & 41.942 & 0 & 0 & 36 \\
\hline 28 & 11 & 37 & 45.942 & 0 & 0 & 32 \\
\hline 29 & 7 & 21 & 50.042 & 23 & 0 & 39 \\
\hline 30 & 27 & 34 & 54.209 & 20 & 0 & 38 \\
\hline 31 & 29 & 32 & 58.709 & 0 & 0 & 41 \\
\hline 32 & 11 & 15 & 63.242 & 28 & 26 & 39 \\
\hline 33 & 30 & 31 & 68.242 & 0 & 0 & 41 \\
\hline 34 & 1 & 8 & 73.392 & 22 & 0 & 37 \\
\hline 35 & 3 & 4 & 79.433 & 24 & 17 & 37 \\
\hline 36 & 19 & 22 & 85.933 & 0 & 27 & 45 \\
\hline 37 & 1 & 3 & 92.500 & 34 & 35 & 44 \\
\hline 38 & 2 & 27 & 99.333 & 0 & 30 & 42 \\
\hline 39 & 7 & 11 & 106.333 & 29 & 32 & 40 \\
\hline 40 & 7 & 20 & 113.783 & 39 & 19 & 45 \\
\hline 41 & 29 & 30 & 121.533 & 31 & 33 & 43 \\
\hline 42 & 2 & 12 & 129.843 & 38 & 18 & 44 \\
\hline 43 & 29 & 33 & 138.426 & 41 & 25 & 46 \\
\hline 44 & 1 & 2 & 150.287 & 37 & 42 & 47 \\
\hline 45 & 7 & 19 & 164.670 & 40 & 36 & 46 \\
\hline 46 & 7 & 29 & 194.180 & 45 & 43 & 47 \\
\hline 47 & 1 & 7 & 330.021 & 44 & 46 & 0 \\
\hline
\end{tabular}


Journal of Fashion Business Vol.17, No.6

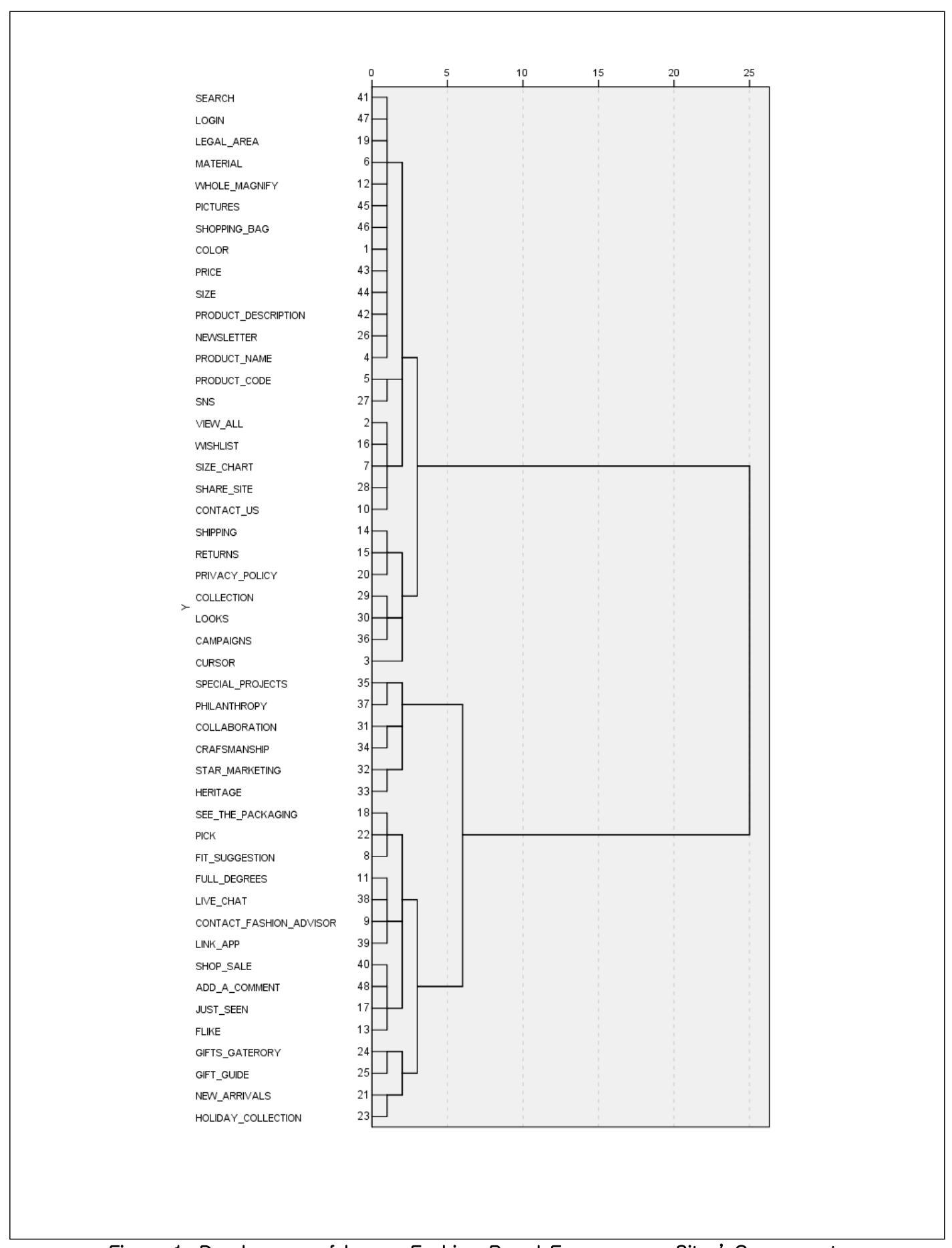

Figure 1. Dendrogram of Luxury Fashion Brand E-commerce Sites' Components 
The dendrogram of components (Figure 1) shows how the groups of e-commerce site elements are categorized. The first group included basic components (e.g., shopping bag, product, color, product description, picture, etc.). The second group was composed of components for brand identity (special projects, philanthropy, collaboration, craftsmanship, star marketing and heritage) the third group were consisted of additional components (e.g., live chat, fit suggestion, just seen, contact fashion advisor, gift guide, new arrival, etc.).

\section{4-2. Clusters of luxury fashion brand e-commerce sites}

To analyze how luxury fashion brands e-commerce sites were segmented, luxury brands' e-commerce sites were clustered by hierarchical cluster analysis. Ward's method and

Table 4. Agglomeration Schedule of Luxury Fashion Brands E-commerce Sites

\begin{tabular}{|c|c|c|c|c|c|c|}
\hline \multirow{2}{*}{ Stage } & \multicolumn{2}{|c|}{ Cluster Combined } & \multirow{2}{*}{ Coefficients } & \multicolumn{2}{|c|}{ Stage Cluster First Appears } & \multirow{2}{*}{ Next Stage } \\
\hline & Cluster 1 & Cluster 2 & & Cluster 1 & Cluster 2 & \\
\hline 1 & 26 & 29 & 1.000 & 0 & 0 & 11 \\
\hline 2 & 11 & 28 & 3.000 & 0 & 0 & 14 \\
\hline 3 & 2 & 19 & 5.500 & 0 & 0 & 7 \\
\hline 4 & 9 & 17 & 8.000 & 0 & 0 & 8 \\
\hline 5 & 4 & 27 & 11.000 & 0 & 0 & 11 \\
\hline 6 & 16 & 22 & 14.000 & 0 & 0 & 12 \\
\hline 7 & 2 & 30 & 17.500 & 3 & 0 & 10 \\
\hline 8 & 9 & 12 & 21.000 & 4 & 0 & 21 \\
\hline 9 & 6 & 10 & 24.500 & 0 & 0 & 20 \\
\hline 10 & 2 & 20 & 28.250 & 7 & 0 & 19 \\
\hline 11 & 4 & 26 & 32.250 & 5 & 1 & 15 \\
\hline 12 & 16 & 24 & 36.583 & 6 & 0 & 24 \\
\hline 13 & 5 & 21 & 41.083 & 0 & 0 & 28 \\
\hline 14 & 1 & 11 & 45.750 & 0 & 2 & 18 \\
\hline 15 & 3 & 4 & 50.550 & 0 & 11 & 22 \\
\hline 16 & 7 & 18 & 55.550 & 0 & 0 & 19 \\
\hline 17 & 8 & 14 & 61.050 & 0 & 0 & 24 \\
\hline 18 & 1 & 25 & 66.633 & 14 & 0 & 23 \\
\hline 19 & 2 & 7 & 72.383 & 10 & 16 & 27 \\
\hline 20 & 6 & 31 & 78.217 & 9 & 0 & 25 \\
\hline 21 & 9 & 13 & 85.217 & 8 & 0 & 22 \\
\hline 22 & 3 & 9 & 92.972 & 15 & 21 & 30 \\
\hline 23 & 1 & 15 & 101.122 & 18 & 0 & 26 \\
\hline 24 & 8 & 16 & 109.889 & 17 & 12 & 26 \\
\hline 25 & 6 & 23 & 118.806 & 20 & 0 & 27 \\
\hline 26 & 1 & 8 & 128.406 & 23 & 24 & 29 \\
\hline 27 & 2 & 6 & 138.856 & 19 & 25 & 28 \\
\hline 28 & 2 & 5 & 149.739 & 27 & 13 & 29 \\
\hline 29 & 1 & 2 & 165.692 & 26 & 28 & 30 \\
\hline 30 & 1 & 3 & 184.774 & 29 & 22 & 0 \\
\hline
\end{tabular}




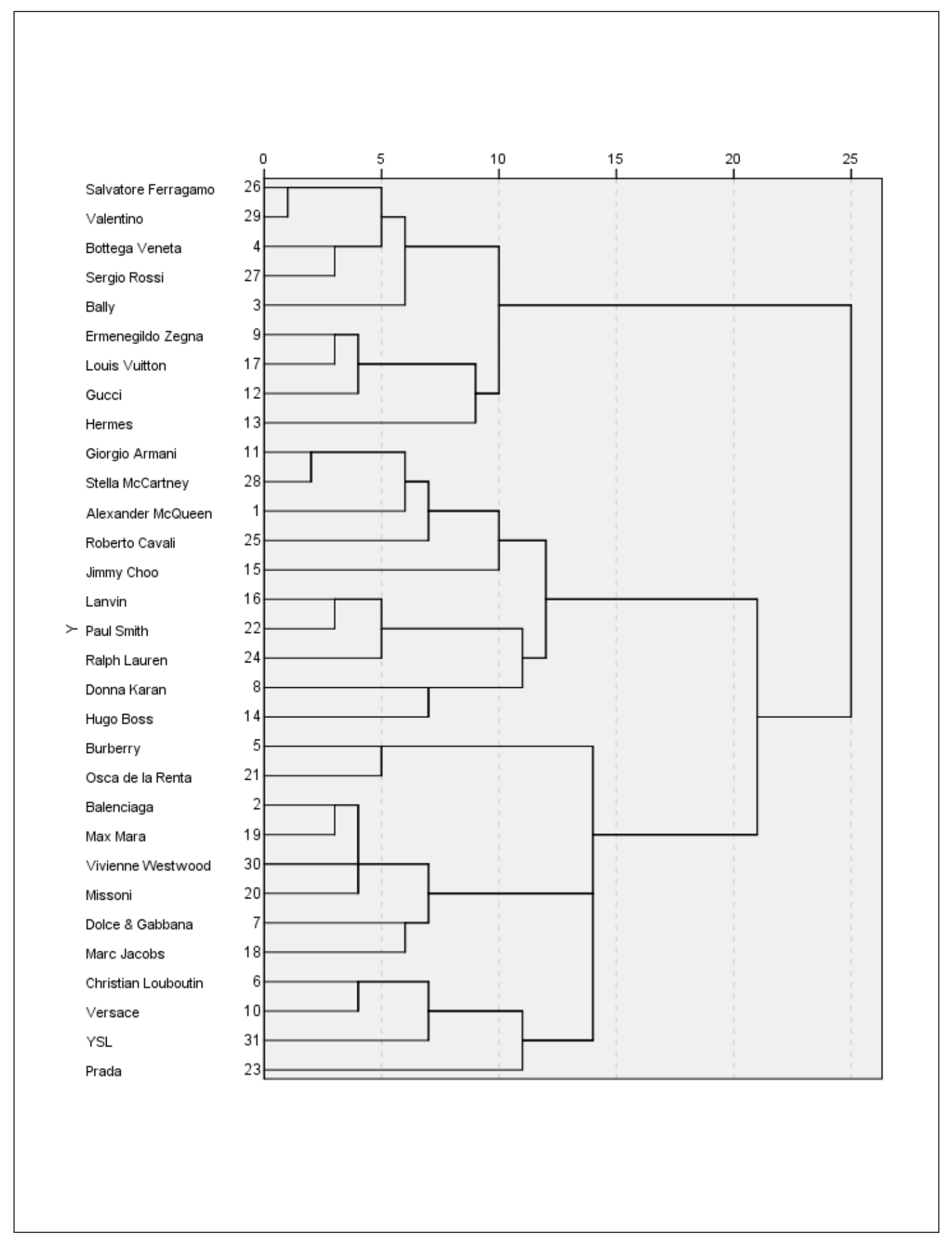

Figure 2. Dendrogram of Luxury Fashion Brand E-commerce Sites 
squared Euclidean distance for binary data set were used. The number of clusters of cases was determined by agglomeration schedule of table 4. There was a large jump between stages 29 and 30. But the luxury brands were clustered into three groups based on the interpretation of Hair et al. (as cited in H. Lee \& Lim, 2013).

The dendrogram of figure 2 shows three groups. The first group included ten brands: Alexander McQueen, Donna Karan, Giorgio Armani, Hugo Boss, Jimmy Choo, Lanvin, Paul Smith, Ralph Lauren, Roberto Cavali, and Stella McCartney. The second group was consisted of twelve brands: Balenciaga, Burberry, Christian Louboutin, Dolce \& Gabbana, Marc Jacobs, Max Mara, Missoni, Oscar de la Renta, Prada, Versace, Vivienne Westwood, and YSL. The third group contained nine brands: Bally, Bottega Veneta, Ermenegildo Zegna, Gucci, Hermes, Louis Vuitton, Salvatore Ferragamo, Sergio Rossi, and Valentino.
In order to name the groups, Fisher's exact test was applied. Twelve components among forty-eight components were statistically significant (Table 5). These twelve components were shipping, return, new arrival, gift category, gift guide, link the app, sale, collaboration, star marketing, heritage, craftsmanship, and special projects.

Group I showed a significant difference in new arrival, gift category, and gift guide. Therefore this group was entitled "the group of promoting goods." Group III presented a significant difference in collaboration, star marketing, heritage, craftsmanship, and special projects. Thus it was named "the group of intensifying brand identity." Group ॥ displayed the lowest performance in every aspect. As a result, it was labeled "the group of undistinguished performance." These groups and their characteristics were shown in the table 6 .

Table 5. Fisher's Exact Test for the Groups of Luxury Brands and E-commerce Site Components

\begin{tabular}{l|c|c|c|c|c}
\hline \multicolumn{1}{|c|}{ Group } & $\begin{array}{c}\text { G1 } \\
\text { The group of } \\
\text { promoting } \\
\text { goods }\end{array}$ & $\begin{array}{c}\text { G2 } \\
\text { The group of } \\
\text { undistinguished } \\
\text { performance }\end{array}$ & $\begin{array}{c}\text { G3 } \\
\text { The group of } \\
\text { intensifying } \\
\text { brand identity }\end{array}$ & $\begin{array}{c}\text { Fisher's } \\
\text { Exact } \\
\chi^{2}\end{array}$ & $\mathrm{p}$ \\
\hline Shipping & $10(38.5 \%)$ & $7(26.9 \%)$ & $9(34.6 \%)$ & 7.511 & 0.007 \\
\hline Return & $10(41.7 \%)$ & $5(20.8 \%)$ & $9(37.5 \%)$ & 12.477 & 0.000 \\
\hline New arrival & $6(52.9 \%)$ & $9(35.3 \%)$ & $2(11.8 \%)$ & 8.927 & 0.011 \\
\hline Gift category & $9(69.2 \%)$ & $2(15.4 \%)$ & $2(15.4 \%)$ & 13.737 & 0.001 \\
\hline Gift guide & $8(66.7 \%)$ & $2(16.7 \%)$ & $2(16.7 \%)$ & 10.021 & 0.008 \\
\hline Collaboration & $6(40.0 \%)$ & $1(6.7 \%)$ & $8(53.3 \%)$ & 14.532 & 0.001 \\
\hline Star marketing & $4(28.6 \%)$ & $2(14.3 \%)$ & $8(57.1 \%)$ & 10.889 & 0.005 \\
\hline Heritage & $4(20.0 \%)$ & $7(35.0 \%)$ & $9(45.0 \%)$ & 8.187 & 0.016 \\
\hline Craftsmanship & $3(25.0 \%)$ & $1(8.3 \%)$ & $8(66.7 \%)$ & 14.242 & 0.000 \\
\hline Special projects & $6(33.3 \%)$ & $4(22.2 \%)$ & $8(44.4 \%)$ & 6.390 & 0.039 \\
\hline Link the App & $2(33.3 \%)$ & $0(0 \%)$ & $4(66.7 \%)$ & 6.221 & 0.020 \\
\hline Sale & $3(100 \%)$ & $0(0 \%)$ & $0(0 \%)$ & 4.894 & 0.045 \\
\hline \hline
\end{tabular}


Table 6. Characteristics of Groups

\begin{tabular}{l|l|c}
\hline \multicolumn{1}{c|}{ Group } & \multicolumn{1}{c|}{ Brands } & \multicolumn{1}{c}{ Main Attributes } \\
\hline $\begin{array}{l}\text { G1. } \\
\text { The group of promoting goods }\end{array}$ & $\begin{array}{l}\text { Alexander McQueen, Donna Karan, Giorgio } \\
\text { Armani, Hugo Boss, Jimmy Choo, Lanvin, Paul } \\
\text { Smith, Ralph Lauren, Roberto Cavali, Stella } \\
\text { McCartney }\end{array}$ & $\begin{array}{c}\text { New arrival, } \\
\text { Gift category, } \\
\text { Gift guide }\end{array}$ \\
\hline $\begin{array}{l}\text { G2. } \\
\text { The group of undistinguished } \\
\text { performance }\end{array}$ & $\begin{array}{l}\text { Balenciaga, Burberry, Christian Louboutin, Dolce } \\
\text { Oscar de la Renta, Prada, Versace, Vivienne } \\
\text { Westwood, YSL }\end{array}$ & $\begin{array}{l}\text { unremarkable } \\
\text { performance }\end{array}$ \\
\hline $\begin{array}{l}\text { G3. } \\
\text { The group of intensifying } \\
\text { brand identity }\end{array}$ & $\begin{array}{l}\text { Bally, Bottega Veneta, Ermenegildo Zegna, } \\
\text { Gucci, Hermes, Louis Vuitton, Salvatore } \\
\text { Ferragamo, Sergio Rossi, Valentino }\end{array}$ & $\begin{array}{c}\text { Collaboration, } \\
\text { Star marketing, } \\
\text { Heritage, } \\
\text { Craftsmanship, } \\
\text { Special Projects }\end{array}$ \\
\hline \hline
\end{tabular}

\section{Discussion and implications}

The main purpose of this study was to investigate how luxury fashion brands' e-commerce site components were categorized and these luxury fashion brands e-commerce sites were segmented. The result indicated that the components of e-commerce sites were grouped into three categories: basic elements, additional elements, and elements of building brand identity. Unlike the study of Spiller \& Lohse (1998), the components were clustered by their function. Namely, it did not matter what categories these components were belong to (e.g., merchandise, service, promotion and convenience) but it was important whether the function of e-commerce site components were basic and essential or additional and advanced. And the other norm of the categories was strengthening brand identity. Thus if e-retailers can recognize what elements are basic or additional and which elements can be used to create brand identity, they can successfully maneuver components and create luxury atmosphere of the site.

From the cluster analysis of segmenting luxury fashion brand e-commerce sites, three groups were classified and were named by their characteristics: the group of promoting goods, the group of undistinguished performance, and the group of intensifying brand identity. For segmenting e-commerce sites, brand identity aspects and promotional aspects played an important role. Thus e-retailers need to manage these aspects for strategically positioning their brands.

As mentioned earlier, in the face of the global economic turmoil, luxury brands had to adapt to changes in context. The e-commerce was new solution for many luxury brands that was not only a method to pass through the crisis but also a rapid response to new digital trend. And it could successfully intrigue affluent consumers to shop online.

As a competition for access to this valuable market were growing, luxury brands were trying to convey their traditional strength to their e-commerce site to achieve online brand reputation. According to the findings of the 
study, luxury e-retailers added a core part of luxury retail mix like elements of intensifying brand identity (heritage, craftsmanship, star marketing, special project, collaboration, etc.) or promotional aspects (new arrival, gift category, gift guide, etc.) to e-commerce sites based on e-commerce strategy. Then they could create different atmosphere away from other ordinary brands and also other luxury competitors.

Generating the culture of luxury is a vital key for luxury e-commerce that can maintain luxury brand's allure and integrity through the e-commerce site. For that reason, this study tried to find luxury e-commerce site component mix and e-commerce segmentation. Therefore the results can provide a better understanding of the luxury e-commerce and retailers can build their strategies and differentiate themselves from the competitors with reference to the result. But it has to be noted that an accurate interpretation and generalization of the results are limited because of the relatively small sample size of data; there was not enough number of luxury e-commerce sites yet. This study suggested the luxury brands e-commerce site's elements and luxury e-commerce market segmentation but luxury consumers' evaluation of the sites was not conducted yet. Therefore it is necessary to analyze luxury e-commerce consumers so as to coordinate their evaluation and needs with the structure of e-commerce site to intensify site quality in the future.

\section{References}

Ahn, K., Lee, J., \& Jeon, J. (2008). The effect of luxury brand-self identification on brand attachment and brand commitment: The moderating role of regulatory focus. Korean
Journal of Marketing, 10(4), 1-33.

Ahn, T., Ryu, S., \& Han, I. (2004). The impact of the online and offline features on the user acceptance of Internet shopping malls. Electronic Commerce Research and Applications, 3, 405-420.

Aladwani, A. M., \& Palvia, P. C. (2002). Developing and validating an instrument for measuring user-perceived web quality. Information \& Management, 39, 467-476.

Armatulli, C., \& Guido, G. (2011). Determinants of purchasing intention for fashion luxury goods in the Italian market: A laddering approach. Journal of Fashion Marketing and Management, 15(1), 123-136.

Baloglu, S., \& Pekcan, Y. A. (2006). The website design and internet site marketing practices of upscale and luxury hotels in Turkey. Tourism Management, 27, 171-176.

Beverland, M. (2004). Uncovering 'theories-in-use': building luxury wine brands. European Journal of Marketing, 38(3/4), 446-466.

Choi, E., Hong, K., \& Lee, Y. (2010). Korean consumers' perceptions toward luxury products. Journal of Fashion Business, 14(5), 195-215.

Choi, M., \& Kim, K. (2005). A study on symbolic color shown from the luxury brand products: Based on luxury brand handbag. Journal of Design Institute Attached to Kyung Hee University, 8(2), 7-13.

Choi, S., \& Jin, K. (2006). Image management and luxury goods in Korean society: A cultural sociological perspective. The Journal of the Korean Society for Clothing Industry, 8(6), 672-678.

Choi, Y., \& Rhee, E. (2004). Dimensions of brand equity of luxury fashion brands (part I). Journal of the Korean Society of Clothing and 
Textiles, 28(7), 1007-1018.

Dubois, B., \& Czellar, S. (2002). Prestige brands or luxury brands? An exploratory inquiry on consumer perceptions. 31st European Marketing Academy Conference (pp.1-9). Portugal: University of Minho. Retrieved

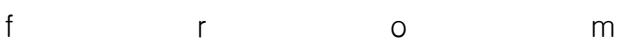

Dubois, B., Czellar, S., \& Laurent, G. (2005). Consumer segments based on attitudes toward luxury: Empirical evidence from twenty countries, Marketing letters, 16(2), 115-128.

Dubois, B., Laurent, G., \& Czellar, S. (2001). Consumer rapport to luxury: Analyzing complex and ambivalent attitudes (pp.1-56). France: HEC School of Management. Retrieved from http://www.hec.fr/var/ corporate/storage/original/application/5213a58e 65910ec4c9cba545dbdc6ca8.pdf.

Galloway, S. (2012, October 4). Digital IQ index: Fashion (L2 Report Fashion 2012). Retrieved from L2 website: http://www.l2thinktank. com/research/fashion-2012.

Han, S. (2007). The analysis of luxury consumer's buying behavior based on luxury consuming experience. Journal of Korean Home Management Association, 25(3), 137-149.

Hennings, N., Wiedmann, K.-P., Behrens, S., Klarmann, C., \& Carduck, J. (2013). Brand extensions: A successful strategy in luxury fashion branding? Assessing consumers' implicit associations. Journal of Fashion Marketing and Management, 17(4), 390-402.

Huizingh, E. K. R. E. (2000). The content and design of web sites: an empirical study. Information \& Management, 37, 123-134.

Jung, J. (2010). The sources of competitive advantage of a global luxury brand firm: Based on the case of LVMH. The Studies of
Professional Managers, 13(3), 117-149.

Kim, S., \& Chung, M. (2006). The effect of consumers' brand identification of fashion luxury product on brand affect and brand loyalty. Journal of the Korean Society of Clothing and Textiles, 30(7), 1126-1134.

Kim, S., \& Kim, G. (2009). The effect of consumer's brand attachment of fashion luxury product on brand loyalty. The Research Journal of the Costume Culture, 17(1), 1-14.

Kim, T., \& Kim, M. (2010). The effects of the web site's characteristics on the seller's satisfaction in the e-marketplace: The case of auction site. The E-Business Studies, 11(4), 29-49.

Koo, D. (2006). The fundamental reasons of e-consumers' loyalty to an online store. Electronic Commerce Research Applications, 5, 117-130.

Lee, H., \& Lim, J. (2013). SPSS 20.0 manual. Seoul: Jiphyeonjeon.

Lee, J., \& Kim, R. (2007). Consumer desire for luxury product: Applying the 'theory of triangular desire' to in-depth interviews. Consumer Studies, 18(2), 41-58.

Lee, S. (2006). The effects of consumer-brand relationship on purchasing attitudes toward counterfeits. Journal of the Korean Society of Clothing and Textiles, 30(9/10), 1445-1454.

Lee, Y., \& Kozar, K. A. (2006). Investigating the effect of web site quality on e-business success: An analytic hierarchy process (AHP) approach. Decision Support System, 42, 1383-1401.

Lohse, G. L. \& Spiller, P. (1998, January). Quantifying the effect of user interface design features on cyberstore traffic and sales. CHI' 98 Proceedings of the SIGCHI Conference on Human Factors in Computing Systems (pp. 211-218). ACM Press/Addison-Wesley 
Professional. Retrieved from http://interface. online.fr/Archives/QuantifyingTheEffectOfIHM.pd $f$.

Moore, C. M., \& Birtwistle, G. (2005). The nature of parenting advantage in luxury fashion retailing-the case of Gucci group NV. International Journal of Retail \& Distribution Management, 33(4), 256-270.

Mun, D., \& Hur, W. (2006). The study of luxury brand image construction using cultural marketing: Based on luxury brand image type and cultural marketing role. Journal of Advertising Research, 17(2), 59-82.

O'Cass, A., \& McEwen, H. (2004). Exploring consumer status and conspicuous consumption. Journal of Consumer Behavior, 4(1), 25-39.

Okonkwo, U. (2007). Luxury fashion branding: Trends, tactics, techniques. NY: Palgrave Macmillan.

Panigyrakis, G., \& Koronaki, E. (2011). Luxury brand consumption and cultural influences. 16th International Conference on Corporate and Marketing Communications (PP.170-180). Athens: University of Economics an Business.

Park, H. [Haeshin]. (2010). An analysis of the fashion luxury brand differentiation strategy. Journalof the Korean Society of Design Culture, 16(2), 252-262.

Park, H. [Hierang], \& Hahn, D. (2006). The integrated model to explain the behaviors of purchasing luxury brands of Korean women. Korean Journal of Consumer and Advertising Psychology, 7(2), 195-226.

Park, H. [Hyejung], \& Jeon, K. (2006). Purchasing intentions toward originals and counterfeits: Foreign Fashion luxury brands. The Journal of the Korean Society for Clothing Industry, 8(5), 530-536.

Park, H. [Hyesun], \& Kim, H. (2011). The effect of benefits and online shopping risks on channel selection for luxury fashion items. Journal of the Korean Society of Clothing and Textiles, 35(1), 13-25.

Park, J. [Jina]. (2010). A study on Korean and Japanese consumers' attitudes and consumer knowledge about luxury brands. Journal of the Korean Society of Clothing and Textiles, 34(8), 1303-1318.

Park, J. [Jungwon]. (2008). A study of the brand equity structure of luxury cosmetic brands. The Society of Korean Traditional Costume, 11(3), 31-42.

Park, J. [Juyoung], Lee, S., \& Choi, J. (2008). Influence of consumption value and beliefs on attitudes toward luxury brands. The Journal of the Korean Society for Clothing Industry 10(2), 191-197.

Park, M. (2006). A study on social, economic and cultural features of luxury brand consumption: Focused on the theory of Baudrillard's consumer society. The Journal of the Korean Society for Clothing Industry, 8(2), 183-190.

Ranganathan, C., \& Ganapathy, S. (2002), Key dimensions of business-to-consumer web sites. Information \& Management, 39, 457-465.

Reddy, M., Terblanche, N., Pitt, L., \& Parent, M. (2009). How far can luxury brands travel? Avoiding the pitfalls of luxury extension'. Business Horizons, 52, 187-197.

Rha, J., Rhee, K. Yeo, J., Kim, R., \& Jun, S. (2010). Counterfeit consumption in Korea: Who buys what, and why?. Consumer Studies, 21(1), 273-298.

Rhee, Y. (2008). The role of body image and conspicuous consumption tendency on luxury brand buying behavior. Journal of the Korean Home Economics Association, 46(7),109-120. 
Shin, J., Kong, H., \& Kang, M. (2006). The effects of luxury brand identification on brand affect and brand loyalty. The Studies of Marketing Management Association, 11(1), 39-62.

Shin, S., \& Kim, M. (2006). Marketing strategies of imported fashion luxury brands according to the types of retailers. Journal of the Korean Society of Clothing and Textiles, 30(2), 221-232.

Spiller, P., \& Lohse, G. L. (1997). A classification of internet retail stores. International Journal of Electronic Commerce, 2(2), 29-56. Retrieved from http://citeseerx. ist.psu.edu/viewdoc/download?doi=10.1.1. 39.8958\&rep=rep $1 \&$ type $=$ pdf.
Truong, Y., Simmons, G., McColl, R., \& Kitchen, P. J. (2008). Status and conspicuousness-are they related?, Journal of Strategy of Marketing, 16(3), 189-203.

Tynan, C., McKechnie, S., \& Chhuon C. (2010). Co-crating value for luxury brands. Journal of Business Research, 63, 1156-1163.

Yang. Y., \& Lee, M. (2006). A study on the activation of the internet apparel shopping mall: Focused on the contents of web-site. Journal of the Korean Home Economics Association, 44(5), 109-118.

Yoon, S., \& Han, J. (2008). An exploratory study on market segmentation of luxury brand consumers based on customer value. Consumer Studies, 19(4), 135-159.

Received(Nov. 19, 2013)

Revised(Dec. 10, 2013)

Accepted(Dec. 13, 2013) 